\title{
evaluation of Critical Places on Wax Patterns Of Blades
}

\author{
Irena Kubelková, Aleš Herman \& Ondřej Vrátný
}
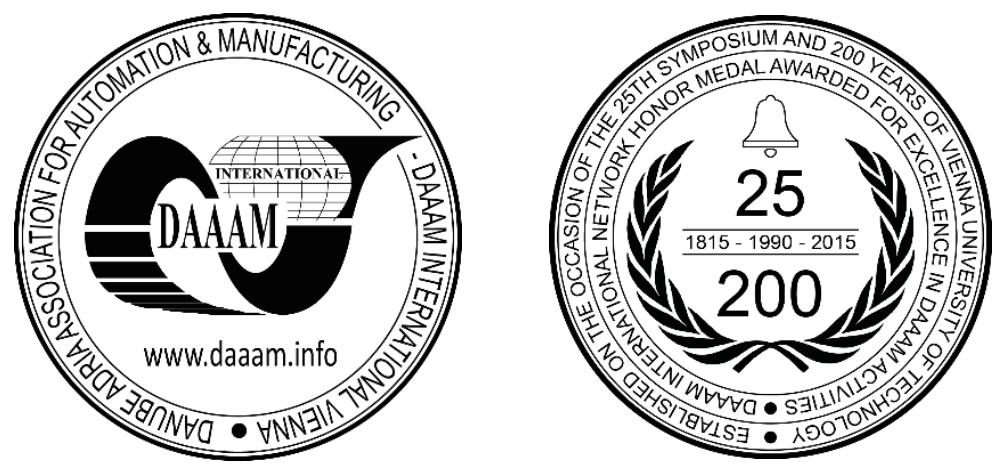

This Publication has to be referred as: Kubelkova, I[rena]; Herman, A[les] \& Vratny, O[ndrej] (2017). Evaluation of Critical Places on Wax Patterns of Blades, Proceedings of the 28th DAAAM International Symposium, pp.1126-1135, B. Katalinic (Ed.), Published by DAAAM International, ISBN 978-3-902734-11-2, ISSN 1726-9679, Vienna, Austria DOI: $10.2507 / 28$ th.daaam.proceedings. 157

\begin{abstract}
The production of precision castings by investment casting is becoming an increasingly important manufacturing industry and many of the pitfalls of this method have to be addressed. This paper deals with evaluation of critical points on wax patterns of blades. After the casting of this type of part, the casting had a deviation from the required dimensions. Investigation revealed that the effect on the resulting dimensional deviation is not only the casting process but also the blade injection process itself. The turbine blade is one of the most important parts in turbine machinery. Casting deformation is an important index to evaluate the quality of the turbine blade. In order to control the deformation of the turbine blade during investment casting, a novel compensation method based on reverse deformation was proposed in this study. The article investigates and evaluates critical points for deformation of the blades after their production on wax-press. In addition, the effect of the pre-deformation preparation and the human factor influencing effect during assembly is evaluated.
\end{abstract}

Keywords: Investment casting; Wax patterns; Deformation; Thermography; Turbine blade

\section{Introduction}

The preparation of the wax pattern is a key procedure in investment casting, playing an important role with the solidification of the metal on the final dimensional accuracy of the casting part. This study considered the injection procedure and the metal solidification as a whole and tried to discover the individual influence of both factors on the dimensional accuracy of the part. [3]

Film cooling is one of most developed technologies which enhance the gas turbine blades operation in today's highthrust-to-weight-ratio gas engines. The determination of the accurate cooling holes of turbine blades is of vital importance to improving the cooling performance. However, in all current methods for manufacturing drilled cooling holes on turbine blades, the complexity of the production processes will ineluctably cause unexpected consequences such as the deformation of the turbomachinery parts, the locating error caused by fixture layouts. These issues will cause deviations in the geometry and position of the drilled holes. In this paper, a methodology is proposed to analyse the deviation and to establish an improved geometric model of drilled cooling holes with accurate positional and geometrical parameters on turbine blades. [4] 


\section{Experiment}

The experiment is divided into 3 parts: the evaluation of critical locations where deformations can occur on wax patterns of blade A, blade B and the third part evaluates the thermal impact of waxy trees during gluing.

Used calibrated equipment and devices:

- Thermographic camera FLIR T640 + evaluation software TOOLS+

- Contact thermometer Ahlborn Therm 2420 with thermocouple FT 106

- CAD software SolidWorks 2015

- Stopwatch

- Tape measure

\subsection{Measurement procedure of blade A}

The blade is pressed onto the injector and set into the rack in the position of the blade lock up.

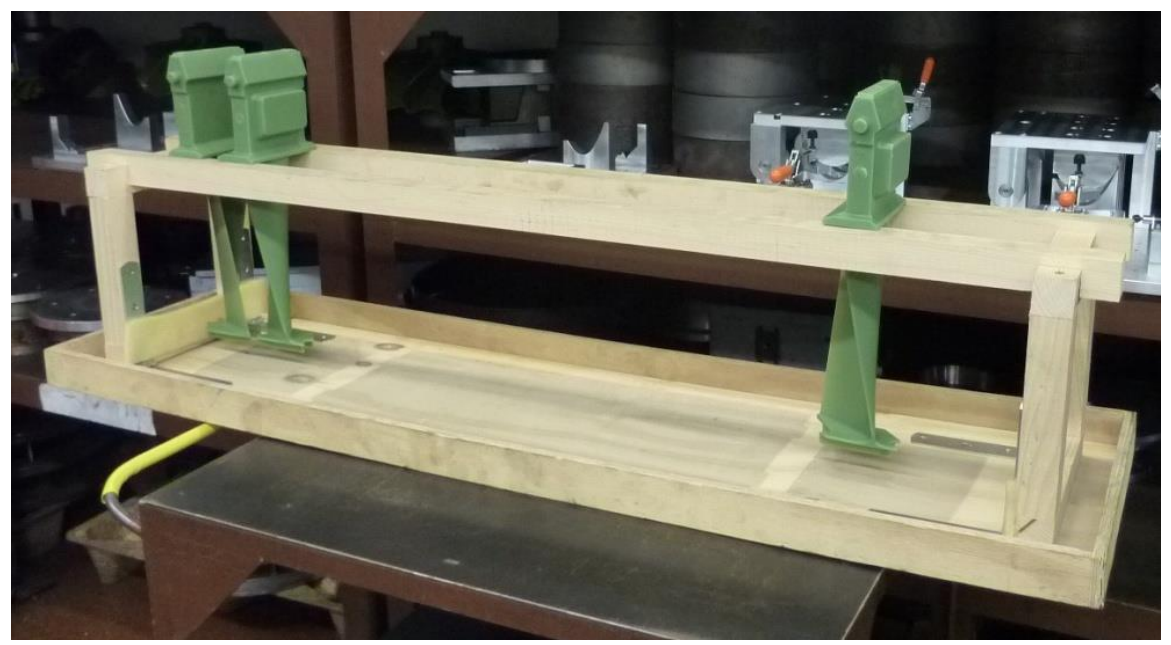

Fig. 1. Placing the blade in the rack

Measuring parameters:

- Ambient temperature $23^{\circ} \mathrm{C}$

- Reflected temperature $23^{\circ} \mathrm{C}$

- Emissions of 0.96

- Distance: $2 \mathrm{~m}$

- Relative Humidity $60 \%$

On this blade the following critical points were evaluated - from side 1 (against the notch) Fig. 3:

- Lock in the strongest place

- The thickest place in the blade (where the blade / cooler is no longer)

- Attaching the lock and blade

- Bandage.

From Side 2 (Slot Link Side) - See Fig. 4:

- The bottom of the blade lock

- Attaching the lock and blade

- Maximum temperature in bandage

- The thickest place in the blade (where the blade / cooler is no longer)

From these pictures it can be seen that the temperature field after removal from the mold is in the functional part of the blade the temperature below the critical $28^{\circ} \mathrm{C}$ only in the bandage, otherwise the temperature is above $33^{\circ} \mathrm{C}$. 


\begin{tabular}{|c|c|c|c|}
\hline Thickness range & Number of areas & Surface area & \% of the analysed area \\
\hline $5,00-7,92 \mathrm{~mm}$ & 103 & $65637,45 \mathrm{~mm}^{2}$ & $40,32 \%$ \\
\hline $7,92-10,84 \mathrm{~mm}$ & 55 & $20244,69 \mathrm{~mm}^{2}$ & $12,44 \%$ \\
\hline $10,84-13,76 \mathrm{~mm}$ & 18 & $6865,77 \mathrm{~mm}^{2}$ & $4,22 \%$ \\
\hline $13,76-16,68 \mathrm{~mm}$ & 6 & $1853,64 \mathrm{~mm}^{2}$ & $1,14 \%$ \\
\hline
\end{tabular}

Table 1. Details of the analysis

\begin{tabular}{|c|c|}
\hline Parameter & Value \\
\hline Total surface area analysed & $162793,01 \mathrm{~mm}^{2}$ \\
\hline Critical surface area (\% of the area under analysis) & $94601,55 \mathrm{~mm}^{2}$ \\
\hline Maximum deviation from target thickness & $11,68 \mathrm{~mm}$ \\
\hline Average weighted critical area thickness & $7,32 \mathrm{~mm}$ \\
\hline Weighted average thickness of the analyzed area & $5,75 \mathrm{~mm}$ \\
\hline Number of critical areas & 182 areas \\
\hline Number of critical elements & 12 \\
\hline Minimum thickness of the analyzed area & $0,00 \mathrm{~mm}$ \\
\hline Maximum thickness of the analyzed area & $16,68 \mathrm{~mm}$ \\
\hline Surface area & $162943,37 \mathrm{~mm}^{2}$ \\
\hline Volume & $465310,13 \mathrm{~mm}^{3}$ \\
\hline Weight & $465,31 \mathrm{~g}$ \\
\hline
\end{tabular}

Table 2. Details of the analysis and physical properties

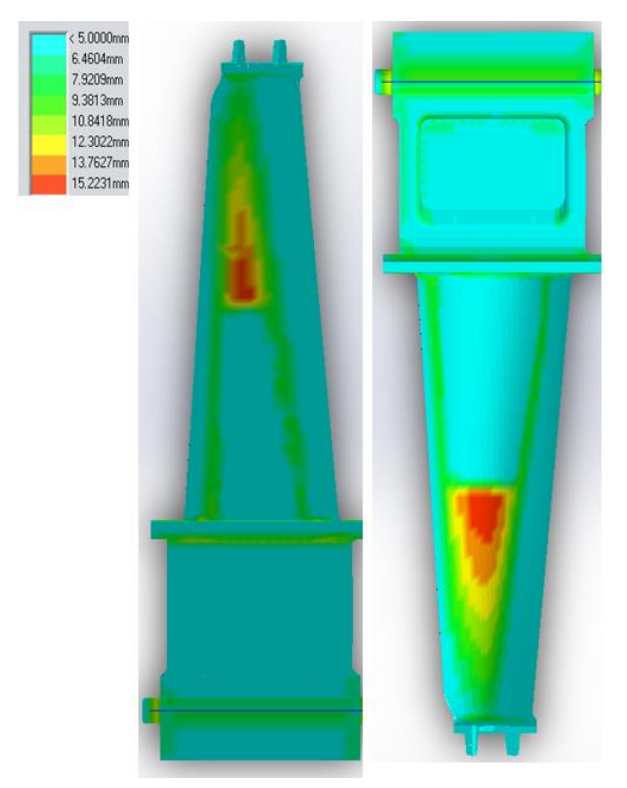

Fig. 2. Graphical thickness analysis SolidWorks

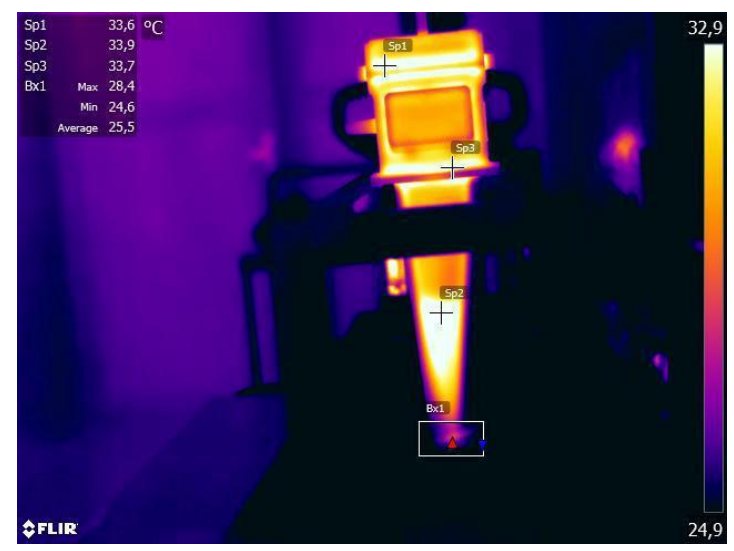

Fig. 3. Blade after removal from mould - side 1 


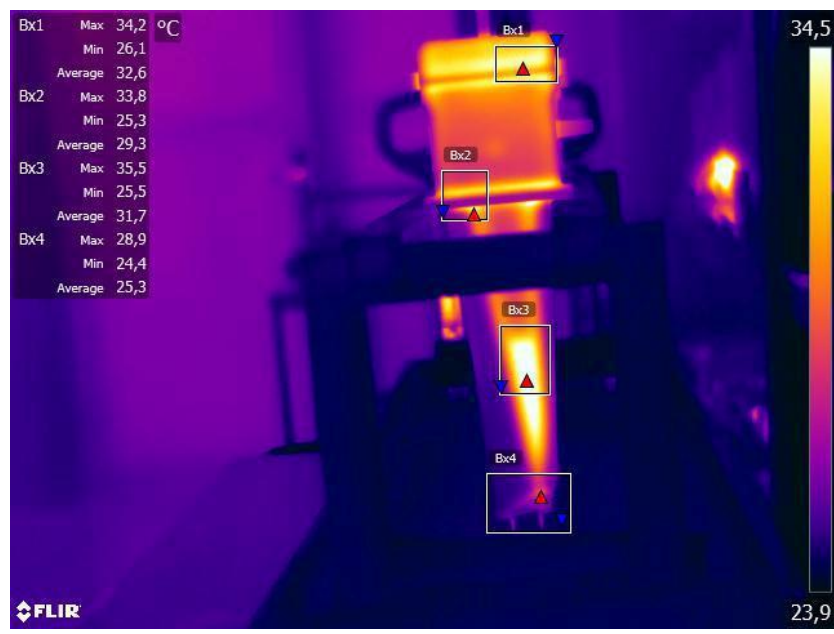

Fig. 4. Blade after removal from mould - side 2

Figure 3 shows a blade without a cooler, that is, just the injected blade space. It can be seen that the cooler is poorly designed - around the lock and the blade of the blade, the thickness of the moulded wax is about 5 - $7 \mathrm{~mm}$, while the area above the cooler has a thickness of up to $17 \mathrm{~mm}$. This is one of the factors that can affect the deformation of this type of model. As shown in Figure 4 the shape of the cooler must be extended to at least the yellow area - here the cooler would be $2-3 \mathrm{~mm}$ thick so that a gap of $5 \mathrm{~mm}$ would occur. The blade cooling is in the correct position - the highest core and surface alignment temperature is over $39^{\circ} \mathrm{C}$. This is, in itself, very critical for deformation of wax models, and it is necessary to apply watering to the water bath after pressing. We recommend the procedure - after inserting it into a fixation device and using a cooling bath at a temperature of $10-15^{\circ} \mathrm{C}$, in order to quickly rinse and fix the position.

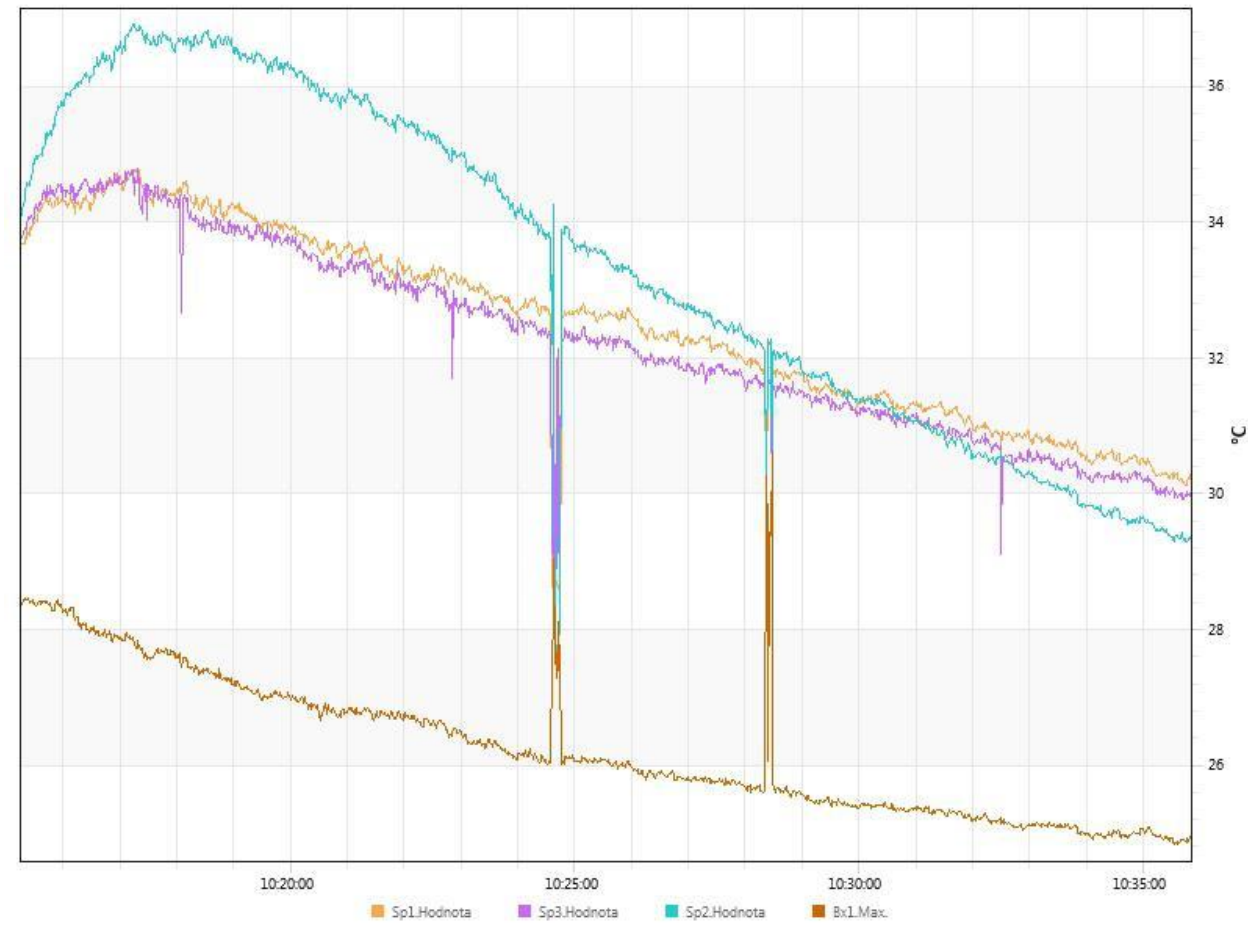

Fig. 5. Temperature range depending on thickness - side 1

From the course of these dependencies it can be seen that the temperature in the critical walls was $34-35^{\circ} \mathrm{C}$ (under the bandage below $28^{\circ} \mathrm{C}$ ) after removal from the mould and standing on the stand. This is, however, a condition where the surface is torn off the injection mould, but the device is warmer. So, in the first few minutes, you can see a temperature increase of up to $39^{\circ} \mathrm{C}$ ( side 1 of a large blade - at the point where there is no blade / chiller in the blade). It can be seen that at the initial temperature after removal from the mould, the surface of the blade returns for 10 to 11 minutes of standing in the upright position - there may be a relatively large deformation due to wax withdrawal during polymerization since the wax is a critical temperature of $28^{\circ} \mathrm{C}$ begins to soften. 


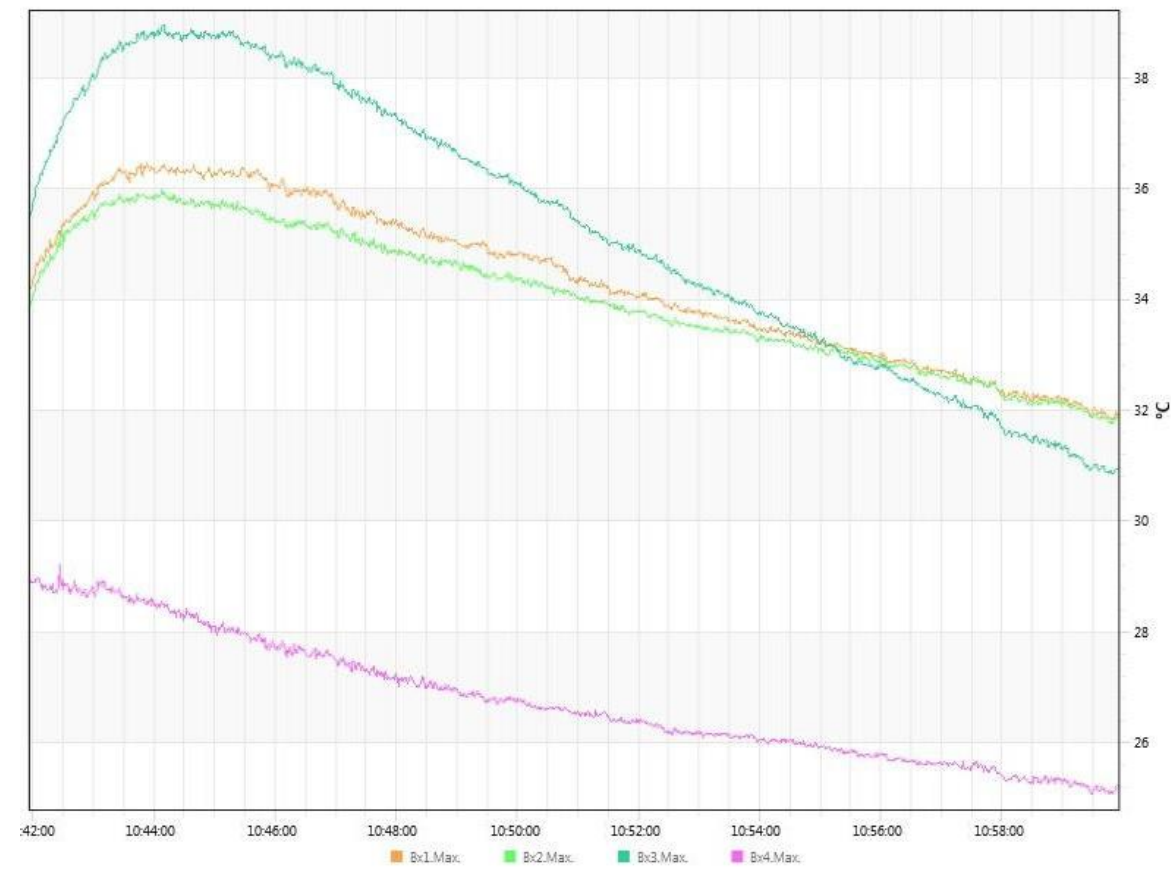

Fig. 6. Temperature range depending on thickness - side 2

\subsection{Measurement procedure of blade $B$}

The blade is pressed onto the injector and set into the rack in the position of the blade lock down.

Measuring parameters:

- Ambient temperature $25^{\circ} \mathrm{C}$

- Reflected temperature $25^{\circ} \mathrm{C}$

- Emissions of 0.96

- Distance: $1 \mathrm{~m}$

- Relative Humidity $60 \%$

On this blade the following critical points were evaluated - from side 1 (against the notch) Fig. 8:

- The thermal node in the bandage

- The thickest place in the castle

- Attaching the lock and blade

- The warmest place against the notch.

From Side 2 (Slot Link Side) - See Figure 9:

- Heat node - connection of notch

- The bottom of the blade lock

- Attaching the lock and blade

- Maximum temperature in bandage

- Temperature in different cuts of different blade thicknesses

\begin{tabular}{|c|c|c|c|}
\hline $\begin{array}{c}\text { Thickness } \\
\text { range }[\mathbf{m m}]\end{array}$ & $\begin{array}{c}\text { Number } \\
\text { of areas }\end{array}$ & $\begin{array}{c}\text { Surface area } \\
{\left[\mathbf{m m}^{\mathbf{2}}\right]}\end{array}$ & $\begin{array}{c}\text { \% of the } \\
\text { analysed } \\
\text { area }\end{array}$ \\
\hline $1,00-3,25$ & 78 & 11049,94 & $46,57 \%$ \\
\hline $3,25-5,50$ & 32 & 4769,17 & $20,10 \%$ \\
\hline $5,50-7,75$ & 12 & 3016,13 & $12,71 \%$ \\
\hline $7,75-10,00$ & 39 & 1245,66 & $5,25 \%$ \\
\hline
\end{tabular}

Table 3. Details of the analysis 


\begin{tabular}{|c|c|}
\hline Parameter & Value \\
\hline Total surface area analysed & $23726,46 \mathrm{~mm}^{2}$ \\
\hline Critical surface area (\% of the area under analysis) & $20080,90 \mathrm{~mm}^{2}$ \\
\hline Maximum deviation from target thickness & $8,99 \mathrm{~mm}$ \\
\hline Average weighted critical area thickness & $3,65 \mathrm{~mm}$ \\
\hline Weighted average thickness of the analyzed area & $4,46 \mathrm{~mm}$ \\
\hline Number of critical areas & 161 areas \\
\hline Number of critical elements & 9 \\
\hline Minimum thickness of the analyzed area & $0,00 \mathrm{~mm}$ \\
\hline Maximum thickness of the analyzed area & $17,05 \mathrm{~mm}$ \\
\hline Surface area & $23741,54 \mathrm{~mm}^{2}$ \\
\hline Volume & $58835,17 \mathrm{~mm}^{3}$ \\
\hline Weight & $58,84 \mathrm{~g}$ \\
\hline
\end{tabular}

Table 4. Details of the analysis

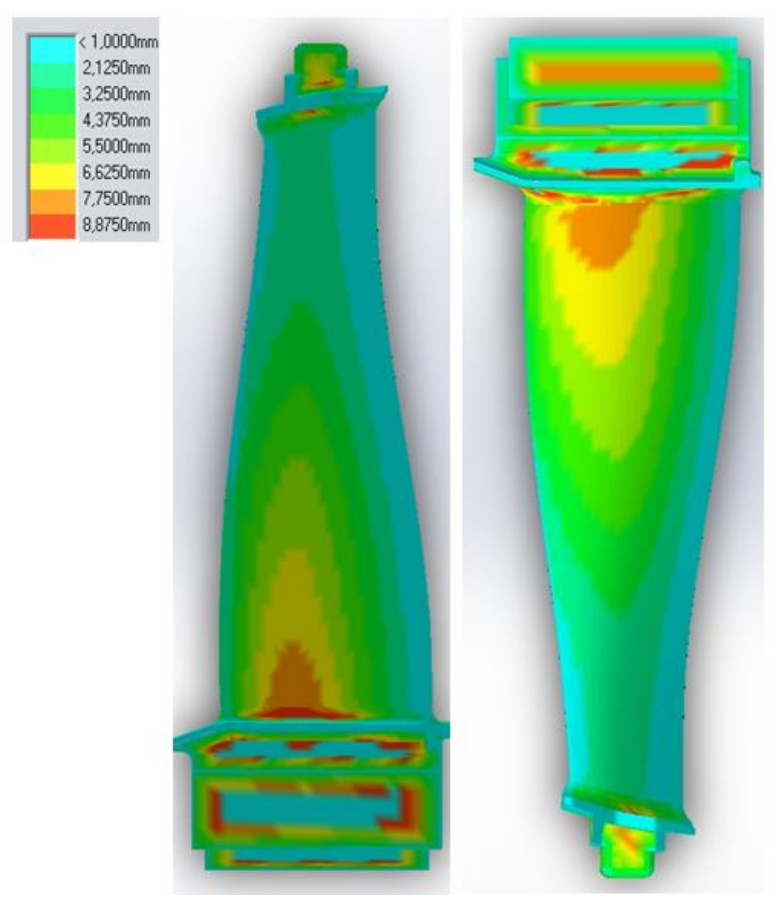

Fig. 7. Graphical thickness analysis SolidWorks

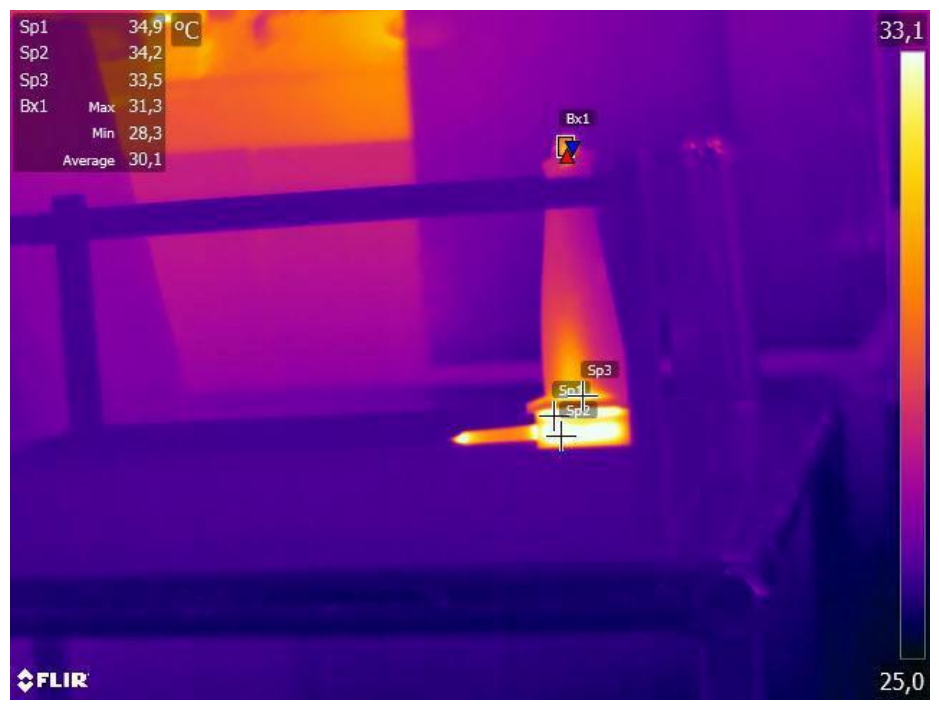

Fig. 8. Blade after removal from mould - side 1 


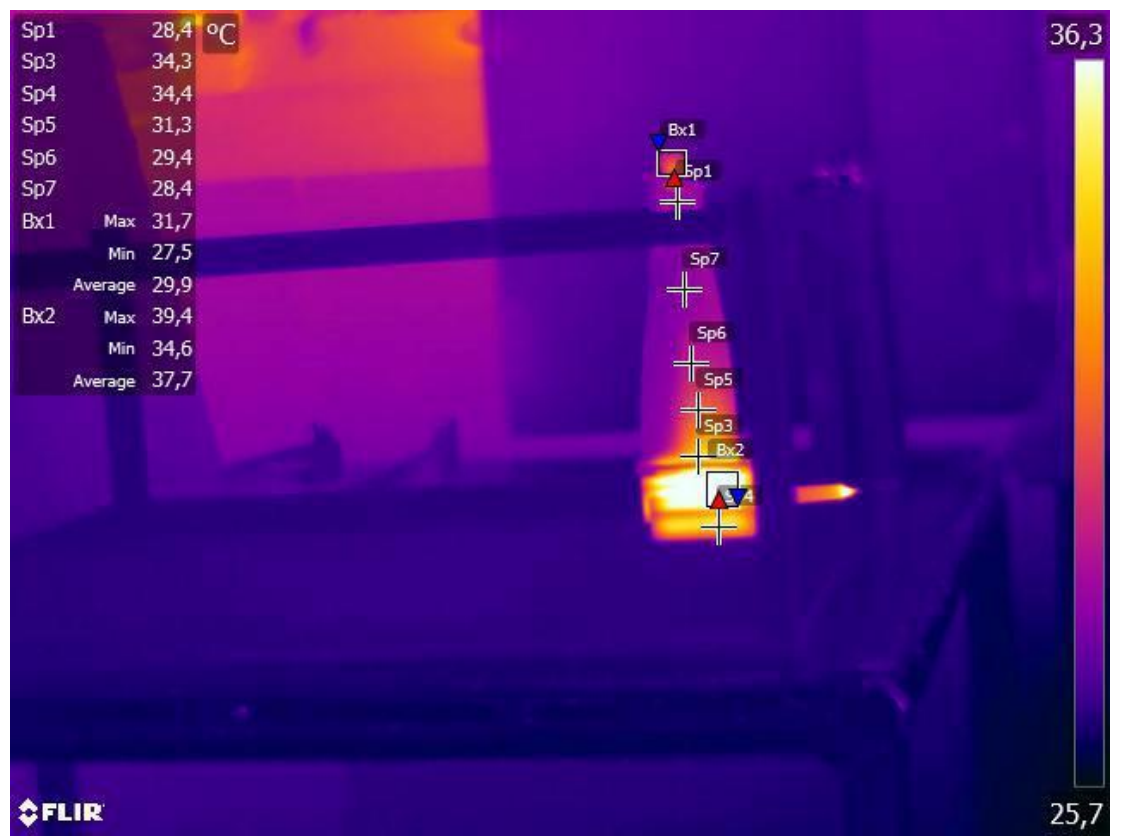

Fig. 9. Blade after removal from mould - side 2

From the course of following dependencies it can be seen that in the critical (strong) walls the temperature was in the range of 30-34 ${ }^{\circ} \mathrm{C}$ after removal from the mold and standing on the stand. This is, however, a condition where the surface is torn off the injection mold, but the device is warmer. So, in the first few minutes, you can see a temperature increase up to $44^{\circ} \mathrm{C}$ (blade B side 2 - connecting the notch to the lock - fig. 8). It can be seen that at the initial temperature after removal from the mold, the blade surface returns for about 10 Minutes standing in the upright position - there may be a relatively large deformation due to the wax withdrawal during polymerization since the wax is a critical temperature of $28^{\circ} \mathrm{C}$ when it begins to soften.

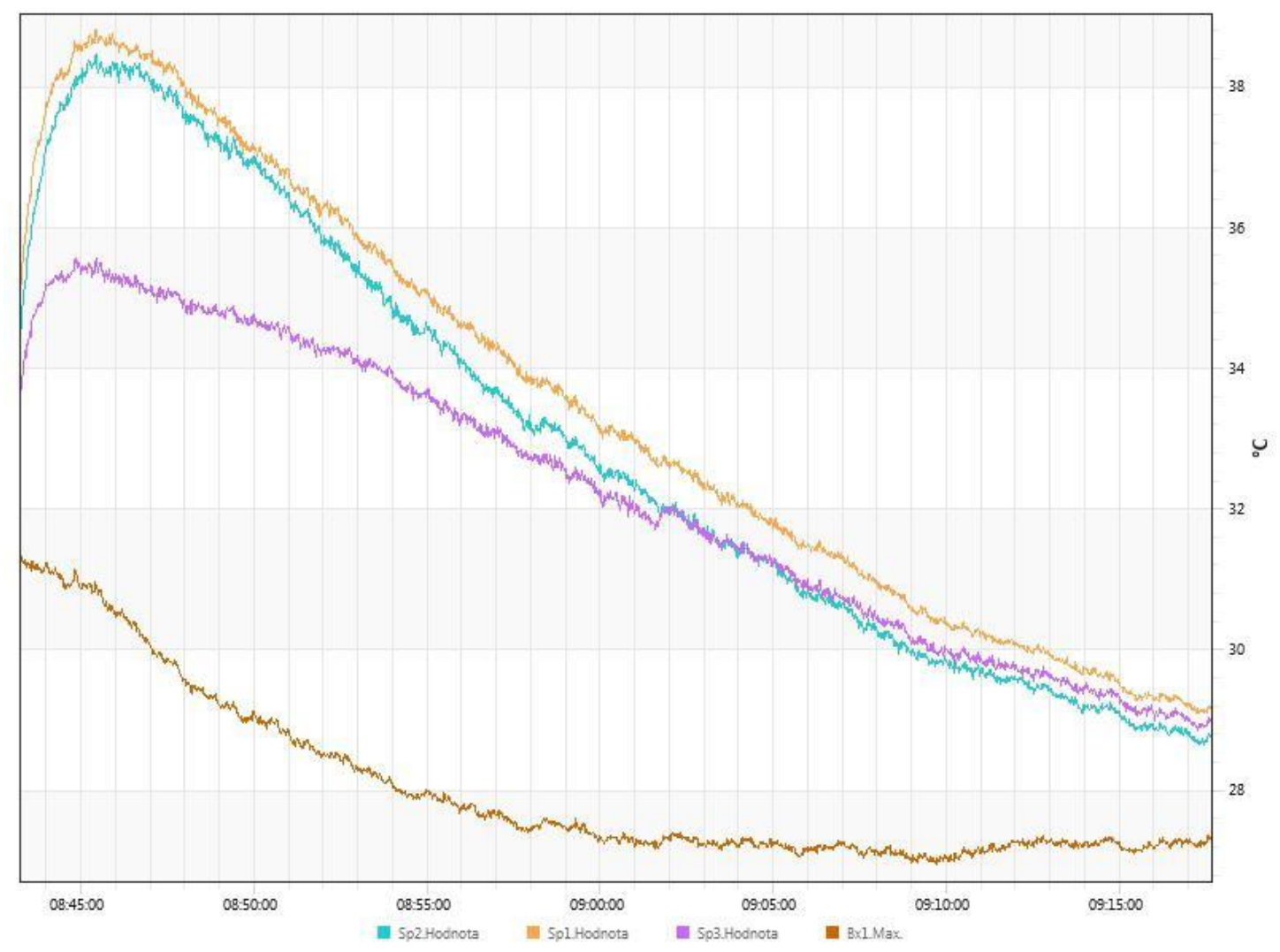

Fig. 10. Temperature range depending on thickness - side 1 


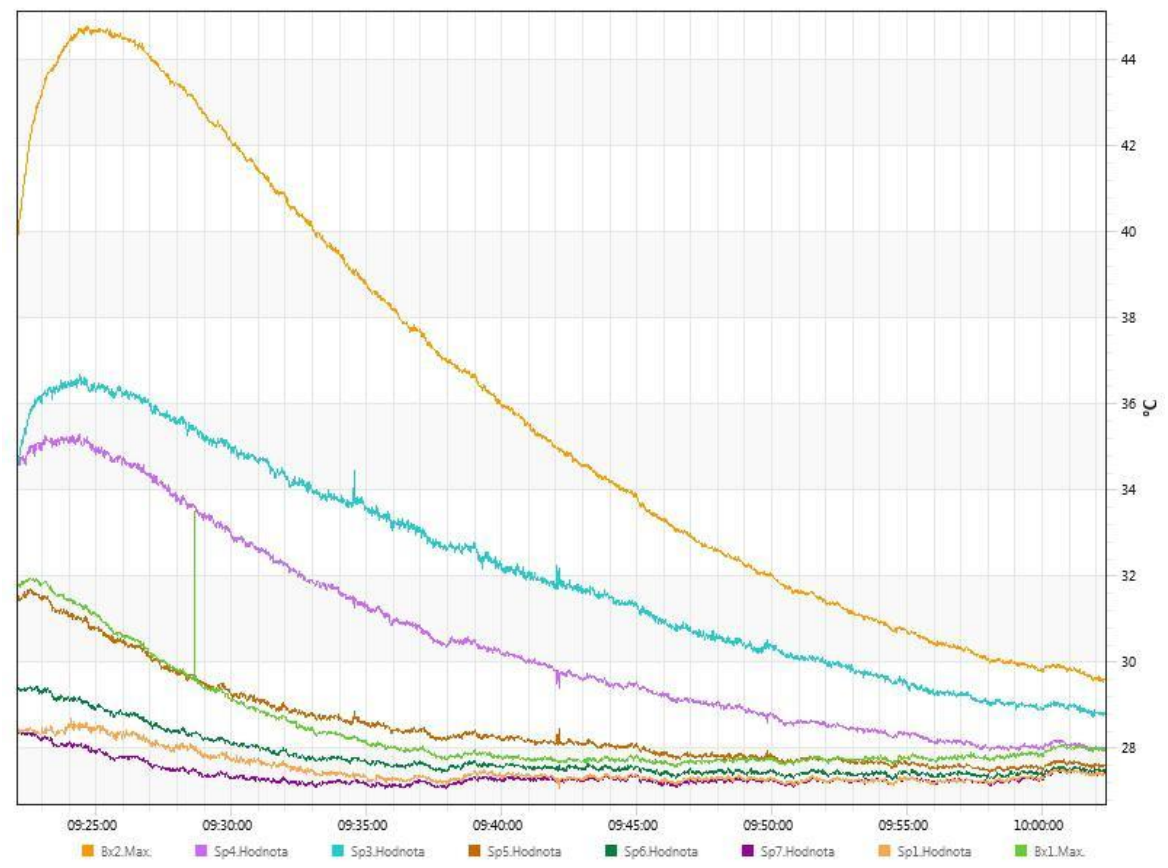

Fig. 11. Temperature range depending on thickness - side 2

Depending on the individual wall thicknesses, the greatest problem in the vane lock and the connection of the inlet system, which is compacted with the vane model, is evident. In this regard, it would be better to stick the inlet part to the model. If we take the shape of a blade, cooling the blade should take place in a hinged form behind the lock, the bandage down (exactly the opposite of what it was found).

\subsection{The influence of cooling in the preparation}

After being removed from the injection molding machine, a large blade is transferred to the stabilizing fixative, where it is allowed to cool for 10 minutes and then transferred to a straightening preparation, where it is cooled for another 10 minutes.

Measuring parameters:

- Ambient temperature $23^{\circ} \mathrm{C}$

- Reflected temperature $23^{\circ} \mathrm{C}$

- Emissions of 0.96

- Distance: $1 \mathrm{~m}$

- Relative Humidity $60 \%$

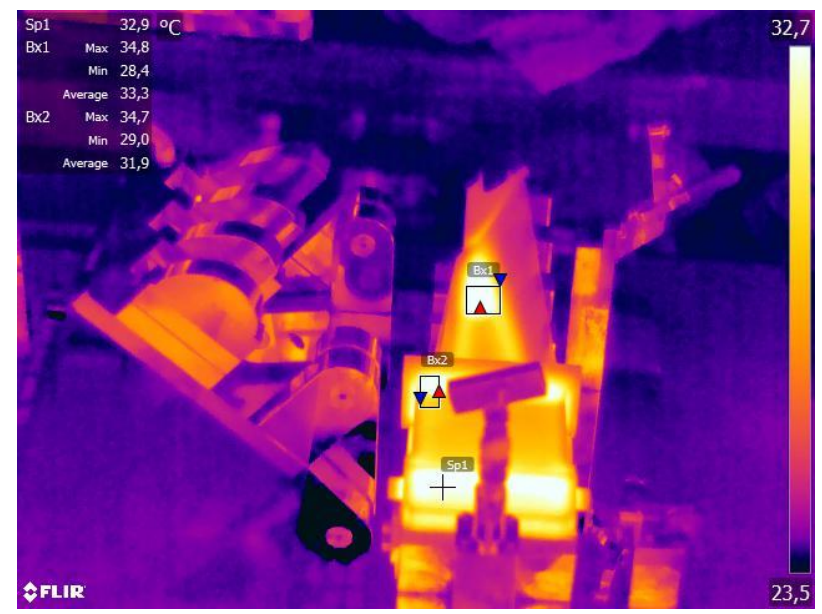

Fig. 12. Insert a blade into the fixative 


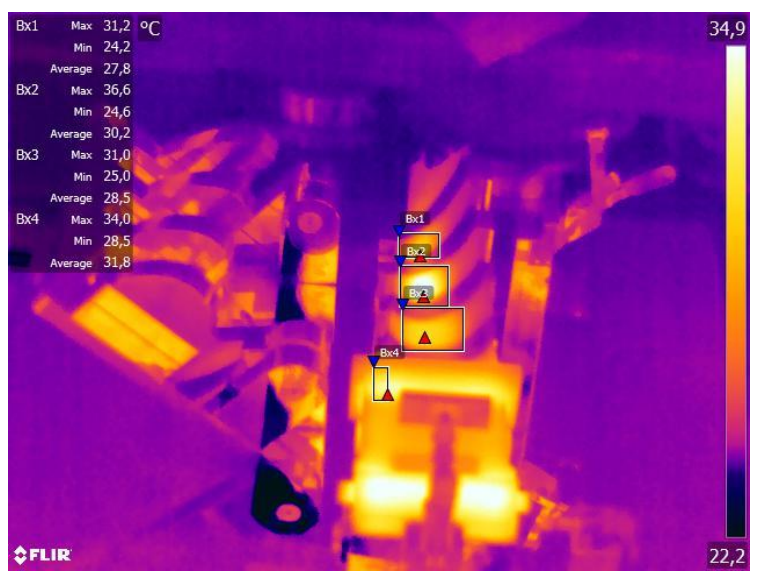

Fig. 13. Opening the fixative after 10 minutes

Figure 12 shows that the temperature distribution corresponds to the temperature field after the removal, recorded on the free-flowing blade in the stand. It can be seen from Figure 13 that despite the use of the fixation device, the temperature is practically at a maximum of $36^{\circ} \mathrm{C}-2^{\circ} \mathrm{C}$ more than it was inserted. In the places where the fixation device touches the vanes, it can be seen that the heat dissipation was more pronounced, but the space between the fins of the fixative is still extremely high. It can be seen from Figure 12 and 13 that it is necessary to quench in a different and substantially faster manner, because the pressing cycle is about 4 minutes and the cooling in the preparation was tested 2.5 times longer than the production cycle of the new wax model of the blade. This results in the need for more products, which is extremely costly in nature (there must be at least 3 fixing and 3 straightening products). Therefore, it is advisable to perform a fixation of the preparation in the cooling water at $10^{\circ} \mathrm{C}$ after removal. This should compensate for the temperature field and the maximum temperature in the blade should not exceed the ambient temperature. This will then ensure dimensional stability of the process

\subsection{Thermal influence of trees on the assembly site}

In the framework of our experience, we have also addressed the possible thermal influence of glued trees on the model workplace. The amount of heat that may be around the workers (whether radiant heat from the plates, maintenance cups or light sources) can affect the temperature rise above $28^{\circ} \mathrm{C}$ and thus impair the dimensional stability of the wax patterns.

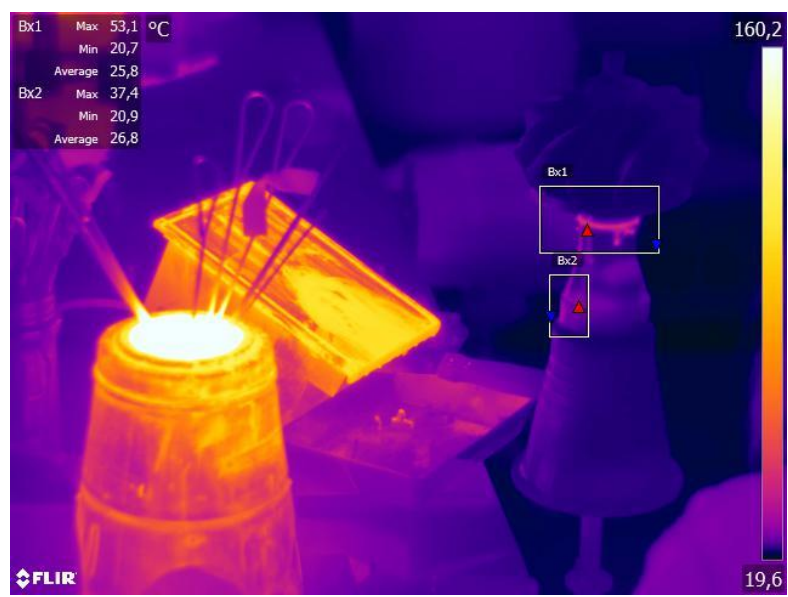

Fig. 14. Figure example

Thermal influences of the tree on Figures 14 show the structure of the workplace for gluing trees and the temperature of the tree placed. Here it is seen that the turbocharger rotor was stuck to the inlet hole in the Bx 1 area, a bonded joint having a maximum temperature of about $53^{\circ} \mathrm{C}$ can be seen. While there was nothing glued to the surface of the gulley, a heat reflection of about $37^{\circ} \mathrm{C}$ is visible. From this it can be seen that there is a significant thermal influence on the adhesive workplace, and it will be necessary to reorganize the workplace - either by moving the glued trees to the other side of the table, or by thermal shading of the heating sources in order not to affect the temperature at the tree. In the next phase, it will be necessary to focus directly on influencing sticking of the blades to the tree and their temperature field at this workplace in order to find a suitable position for bonding that will not affect the dimensional stability of the wax models. 


\section{Conclusion}

The main problem / task of the research were by thermography to determine when the blades deform and prevent this. Based on the results from the thermography image, it is clear that the blades are most deformed during compaction after compression due to the influence of residual heat inside the blades. After evaluating all the measurement results we can give the following recommendations:

- Do not inject the blade B together with the notch - it forms a distinct thermal knot.

- In the case of a blade B, it would be advisable either to use a chiller / chisel (to minimize the thermal knot in the lock) or to use a fuser with cold water

- In the case of a large blade, we have shown a poorly designed chiller / jaw - it should be considerably longer - the blade is a large thermal knot that affects deformation behavior and increases dimensional instability

- Thoroughly tighten the large blade straight after being pressed into the fuser (align it with production so that it requires up to 2 fixation products - the current situation seems to be very unprofitable)

- The workshop for the gluing of trees significantly influences the wax models - it will be necessary to measure the effect on sticking the blades to the tree and, if necessary, to adjust the ergonomics of the workplace so as to avoid any possible influence

The future plants are to analyze other types of blades and describe their production - it will take place in the subsequent period. We will focus especially on the stability of the process, avoiding unwanted deformations of the blades caused by inappropriate thermal control.

\section{Acknowledgments}

This report was created in cooperation with the company První brněnská strojírna Velká Bíteš, and in the form of an economic contract under the project TRIO No. FV10105, Research on the enhancement of the shape accuracy of wax models for turbocharger blade castings and strain gas turbines.

\section{References}

[1] Herman, A.; Vrátný, O.; Kubelková, I. (2016). Vyhodnocení kritických míst na voskových modelech lopatek, Velká Bíteš: PBS Velká Bíteš

[2] Jiang, R., Zhang, D., Bu, K. et al. Int J Adv Manuf Technol (2017) 88: 3195. https://doi.org/10.1007/s00170-0169030-5

[3] Wang, D., He, B., Liu, S. et al. Int J Adv Manuf Technol (2016) 85: 201. https://doi.org/10.1007/s00170-015-78361

[4] Dong, YW.; Zhao,Q.; Li, XI.; Li, XJ. \& Yang, J. (2017). Methodology to develop geometric modeling of accurate drilled cooling holes on turbine blades, proceedings of the ASME Turbo Expo: Turbine Technical Conference and Exposition, AMER Soc Mechanical Engineers, Three Park Avenue, New York, NY 10016-5990 USA, ISBN:9780-7918-5091-6

[5] Hancock, Phil . Technical Report : Wax Evaluation. Cambridge, UK : [S.N.], (2011). 24 Quality Control Manual (Summary). [S.L.] : Blayson Olefines LTD, 200?. 28 S.

[6] Herman, A., Česal, M., A Píša, V. (2014). Měření Vlastností Voskových Směsí Jako Vstupních Dat Do Databáze Simulačního Software. Strojírenská Technologie., XIX(1), S. 8-12. ISSN 1211-4162.

[7] Herman, A., Česal, M., A Mikeš, P. (2012). Problematic Of Model And Castings Deformations In Investment Casting Technology. In: ULEWICZ, Robert A Beneš, L., Eds. New Trends In The Field Of Materials And Technologies Engineering. Czestochowa: Oficyna Wydawnicza Stowarzyszenia Menedzerów Jakości I Produkcji. S. 160-177. ISBN 978-83-934225-2-4.

[8] Bond, David; Nishikawa, Koji.(2013). Investigation Of Wax Expansion. Blayson Technical Lectures. 2002, S. 144.Volume 834-836, 2013, Pages 1575-1579,2013 3rd International Conference On Materials And Products Manufacturing Technology, ICMPMT 2013; Guangzhou; China; 25 September 2013 Through 26 September 2013; Code 100757

[9] Herman, A., Česal, M., A Mikeš, P. (2011). Problematic Of Model And Castings Deformations In Investment Casting Technology. In: Techmat 11. TECHMAT 2011. Svitavy, 10.11.2011. Pardubice: Univerzita Pardubice, Dopravní Fakulta Jana Pernera. 2011, ISBN 978-80-7395-431-4.

[12] Modukuru, S.C.-Ramakrishnan, N.-Sriramamurthy, A.M.(1996). Determination Of The Die Profile For The Investment Casting Of Aerofoil-Shaped Turbine Blades Using The Finite-Element Method. Journal Of Materials Processing Technology 58 (1996) 223-226

[13] Marek, V[aclav] (2016). Basic Research of Thermal Transfer Simulations, Proceedings of the 27th DAAAM International Symposium, pp.0578-0585, B. Katalinic (Ed.), Published by DAAAM International, ISBN 978-3902734-08-2, ISSN 1726-9679, Vienna, Austria DOI: 10.2507/27th.daaam.proceedings.085 